\title{
(JIPD)
}

Jurnal Inovasi Pendidikan Dasar

Vol. 4, No. 2, Bulan Juli Tahun 2020, Hal. 76-85

E-ISSN: 2598-408X, P-ISSN: 2541-0202

http://unikastpaulus.ac.id/jurnal/index.php/jipd

https://doi.org/10.36928/jipd.v4i2.607

\section{MENGENAL LITERASI ETNOMATEMATIKA DALAM BUDAYA MANGGARAI}

\author{
Eliterius Sennen \\ Prodi PGSD Universitas Katolik Indonesia Santu Paulus Ruteng \\ Fakultas Keguruan dan Ilmu Pendidikan, Prodi PGSD \\ Jl. Jend.Ahmad Yani, No.10, Ruteng, 86508 \\ email: eliterius63@gmail.com
}

Diterima: 11 Januari 2020, Direvisi: 15 Mei 2020, Diterbitkan: 15 Juli 2020

\begin{abstract}
In the life of the Manggarai community, numbers 1-10 each have different names or designations. Furthermore, for numbers 10 - 90 there are additional phonemes $/ \mathrm{m} /$ and followed by the word pulu from numbers 1-9, and specifically for multiples of 10 , there is a sound change from / a / to / e /, such as se (ce) mpulu, suampulu, telumpulu, and so on. While numbers 11-19 are a combination of numbers 10 - 90 with numbers 1-9, such as se (ce) mpulu ca, se (ce) mpulu sua, se (ce) mpulu telu, ..., se (ce) mpulu siok (ciok ), suampulu sa / ca, suampulu sua, suampulu telu, ..., suampulu siok / ciok, telumpulu sa (ca), telumpulu sua, telumpulu telu, and so on up to siok (ciok) mpulusiok (ciok). Furthermore, numbers 100 - 900 are called se(ce) ratus, sua ratus, telu ratus, and so on up to Siok (ciok) ratus. Numbers 1000, 2000, 3000, and so on are called ce ribu (ce sebu), sua ribu (sua sebu), telu ribu (telu sebu), and so on. In addition to the base 10 numbers, also found the use of base numbers 2 , base 4 , base 8 , and base 100 as found in the western region of Manggarai. These base numbers 2, base 4, base 8 and base 100 are used in packaging corn. Corn packages consisting of 2 grains are called wasé, packages consisting of 4 grains are called ndurung, packages consisting of 8 grains are called dolé, and packages containing 100 grains or suampulu lima ndurung are called limbung. Various types of tools that are often used by the Manggarai community to say, among others: fingers, corn kernels, dukut réa, with measurement units used are: dalo, héndok, pagat, ciku, depa, dako, tongka, wega and so on. The amount of time is: leso, week, lu'ang / wulang, ntaung, and so on. Length measuring instruments commonly used are Ntawang / Ndawang wasé and wasé ajo, the units of which are meters. The length measuring unit commonly used by the Manggarai community is; dalo, héndok, pagat, ciku, depa, and lampa or nggap.
\end{abstract}

Keywords: Literacy, Ethnomatematics, and Culture.

\begin{abstract}
Abstrak: Dalam kehidupan masyarakat Manggarai, bilangan 1 - 10 masing-masing mempunyai nama atau sebutan yang berbeda. Selanjutnya, untuk bilangan 10 - 90 terdapat tambahan fonem $/ \mathrm{m} /$ dan diikuti kata pulu dari bilangan $1-9$, dan khusus untuk bilangan kelipatan 10, ada perubahan bunyi dari /a/ menjadi /e/, seperti se(ce)mpulu, suampulu, telumpulu, dan seterusnya. Sedangkan bilangan 11 - 19 merupakan gabungan dari bilangan 10 - 90 dengan bilangan $1-9$, seperti se(ce)mpulu ca, se(ce)mpulu sua, se(ce)mpulu telu, ..., se(ce)mpulu siok(ciok), suampulu sa/ca, suampulu sua, suampulu telu, ..., suampulu siok/ciok, telumpulu sa(ca), telumpulu sua, telumpulu telu, dan seterusnya sampai dengan siok(ciok)mpulusiok(ciok). Lebih lanjut, bilangan 100 - 900 disebut se(ce) ratus, sua ratus, telu ratus, dan seterusnya sampai dengan siok(ciok) ratus. Bilangan 1000, 2000, 3000, dan seterusnya disebut dengan ce ribu (ce sebu), sua ribu (sua sebu), telu ribu (telu sebu), dan seterusnya. Selain bilangan basis 10 , ditemukan juga penggunaan bilangan basis 2 , basis 4 , basis 8 , dan basis 100 seperti yang dijumpai di wilayah Manggarai bagian barat. Bilangan basis 2, basis 4, basis 8, dan basis 100 ini digunakan dalam pengemasan jagung. Kemasan jagung yang terdiri dari 2 bulir disebut wasé, kemasan yang terdiri dari 4 bulir disebut ndurung, kemasan yang terdiri dari 8 bulir disebut dolé, dan kemasan yang terdiri dari 100 bulir atau suampulu lima ndurung disebut limbung. Berbagai jenis alat bantu yang sering digunakan oleh masyarakat Manggarai untuk membilang antara lain: jari tangan, biji jagung, dukut ré'a, dengan satuan pengukuran yang digunakan adalah: dalo, héndok, pagat, ciku, depa, dako, tongka, wega dan sebagainya. Besaran waktu adalah: leso, minggu, lu'ang/wulang, ntaung, dan sebagainya. Alat ukur panjang yang biasa digunakan adalah wasé Ntawang/Ndawang dan wasé ajo, yang satuannya adalah meter. Satuan ukur panjang
\end{abstract}


yang biasa digunakan oleh masyarakat Manggarai adalah; dalo, héndok, pagat, ciku, depa, dan lampa atau nggap.

Kata kunci: Literasi, Etnomatematika, dan Budaya.

\section{PENDAHULUAN}

Matematika dan budaya merupakan dua hal yang saling berhubungan satu dengan yang lain. Di satu pihak matematika dibentuk oleh budaya, dan di pihak lain matematika digunakan sebagai alat untuk kemajuan budaya. Dengan demikian, matematika merupakan bagian dari budaya manusia, dan matematika dalam setiap budaya berguna untuk tujuan khusus dari budayanya. Hal ini sejalan dengan pendapat Ernest (Dominikus, 2018: 5) yang menyebutkan bahwa matematika merupakan suatu konstruksi soasial-budaya di mana matematika terkandung dalam sejarah dan aktivivitas manusia. Dalam praktik kehidupan sehari-hari, banyak kegiatan manusia yang berhubungan dengan matematika sehingga dikatakan bahwa matematika adalah kegiatan manusia. Dalam konteks kegiatan manusia, matematika merupakan suatu fnomena yang terkait dengan budaya, sehingga pengelolaan pembelajaran matematika di sekolah perlu dikaitkan dengan budaya atau yang sering disebut sebagai pendekatan etnomatematika.

Pembelajaran matematika dengan pendekatan etnomatematika merupakan pembelajaran berbasis budaya yang menggunakan simbol-simbol budaya untuk memunculkan konsep-konsep matematika. Tulisan ini mengkaji tentang matematika terutama mengenai konsep membilang dan mengukur yang dikaitkan dengan konteks budaya masyarakat Manggarai.

\section{PENGERTIAN BUDAYA ETNOMATEMATIKA}

DAN

\section{Menurut Kamus Bahasa Indonesia} (2008: 225), budaya adalah pikiran, akal budi, adat istiadat. Sedang kebudayaan adalah hasil kegiatan dan penciptaan batin (akal budi) manusia, seperti kepercayaan, kesenian dan adat istiadat. Budaya didefinisikan sebagai seluruh aspek kehidupan manusia dalam masyarakat, yang diperoleh dengan cara belajar, termasuk pikiran dan tingkah laku (Marvins dalam Wahyuni,dkk. 2013:114). Definisi-definisi tersebut menunjukkan bahwa jangkauan kebudayaan sangatlah luas. Untuk memudahkan pembahasan, Ernst Cassirer (Wahyuni, dkk. 3013:114) membaginya menjadi lima aspek: (1)
Kehidupan Spritual; (2) Bahasa dan Kesustraan; (3) Kesenian; (4) Sejarah; dan (5) Ilmu Pengetahuan. Dengan demikian, kebudayaan merupakan sesuatu yang akan mempengaruhi tingkat pengetahuan dan meliputi sistem ide atau gagasan yang terdapat dalam pikiran manusia. Dalam konteks daerah Manggarai kebudayaan berupa benda-benda seni seperti gong, tembong, lodok, caci, dan lain-lain yang diciptakan oleh para leluhur (mbate dise ame, pedeng dise ine).

Sedangkan etnomatematika

(Ethnomathematics) diperkenalkan oleh D'Ambroso dan Nunes (Pannen, 2005: 94) yang menyatakan bahwa etnomatematika sebagai “... the art of comprehending, describing, coping with, and managing both natural and socially contructed systems using techniques such as counting, measuring, soring, ordering, and inferring-developed by well-defined groups like nations, professional classes, children in various age groups, labor groups and so on". Lebih lanjut, Nunes (Pannen, 2005: 94) menjelaskan bahwa etnomatematika merupakan "... study of how various groups and cultures in the world develop and use mathematics".

Matang (2006) menyatakan bahwa etomatematika sebagai "the term used to express the relationship between culture and mathematics". Selanjutnya, Zhang (2010) mendefinisikan etnomatematika sebagai "research on the relationshipbetween mathematics (mathematics education) and the corresponding socialand cultural backgrounds, namely the research shows "how is mathematicsproduced, transferred, diffused and specialized in diverse cultural systems".

$$
\text { Jelaslah bahwa etnomatematika }
$$
merupakan hubungan antara matematika dan budaya tertentu yaitu bagaimana matematika diterapkan oleh kelompok budaya tertentu seperti suku tertentu, kelompok buruh, anak-anak dari masyarakat kelas tertentu, kelas-kelas profesional, dan lain sebagainya. Etnomatematika dipersepsikan sebagai lensa untuk memandang dan memahami matematika sebagai suatu hasil budaya atau produk budaya. Dari konteks pembelajaran matematika dengan pendekatan etnomatematika merupakan pembelajaran berbasis budaya yang 
menggunakan simbol-simbol budaya untuk memunculkan konsep-konsep matematika. Dalam hal ini, pembelajaran matematika yang dihubungkan dengan konteks budaya tertentu merupakan suatu bentuk pembelajaran literasi matematika, suatu pembelajaran yang memungkinkan peserta didik mampu terlibat dalam memecahkan masalah di lingkungan tempat tinggalnya.

\section{LITERASI MEMBILANG BUDAYA MANGGARAI}

Membilang merupakan salah satu aktivitas yang sering dilakukan masyarakat Manggarai. Membilang berkaitan dengan banyaknya sesuatu, jawaban dari pertanyaan berapa banyak. Aktivitas membilang bagi masyarakat Manggarai sering dipakai baik dalam kegiatan sehari-hari maupaun dalam kegiatan yang bernuansa adat. Dengan demikian, mengajak dan memberi kesempatan kepada peserta didik dalam kegiatan pembelajaran membilang sesuai budaya mereka merupakan suatu upaya untuk mengembangkan pembelajaran literasi matematika.

Secara umum penyebutan atau penamaan

DALAM bilangan oleh masyarakat Manggarai menggunakan istilah yang relatif sama, hanya dialek atau logatnya yang berbeda. Adapaun penyebutan atau penamaan bilangan tersebut disajikan pada tabel berikut.

Tabel 1. Bilangan dalam Budaya Manggarai

\begin{tabular}{|l|l|l|l|}
\hline $\begin{array}{l}\text { Lambang } \\
\text { Bilangan }\end{array}$ & $\begin{array}{l}\text { Nama Bilangan dlm } \\
\text { Budaya Manggarai }\end{array}$ & $\begin{array}{l}\text { Lambang } \\
\text { Bilangan }\end{array}$ & $\begin{array}{l}\text { Nama Bilangan dalam Budaya } \\
\text { Manggarai }\end{array}$ \\
\hline 1 & Sa(Ca) & 21 & Suampulu sa(ca) \\
\hline 2 & Sua & 22 & Suampulu sua \\
\hline 3 & Telu & 23 & Suampulu telu \\
\hline 4 & Pat & 24 & Suampulu pat \\
\hline 5 & Lima & 25 & Suampulu lima \\
\hline 6 & Enem & 26 & Suampulu enem \\
\hline 7 & Pitu & 27 & Suampulu pitu \\
\hline 8 & Alo & 28 & Suampulu alo \\
\hline 9 & Siok(ciok) & 29 & Suampulu siok(ciok) \\
\hline 10 & Se(ce)mpulu & 30 & Telumpulu \\
\hline 11 & Se(ce)mpulu sa(ca) & 40 & Patmpulu \\
\hline 12 & Se(ce)mpulu sua & 50 & Limampulu \\
\hline 13 & Se(ce)mpulu telu & 60 & Enemmpulu \\
\hline 14 & Se(ce)mpulu pat & 70 & Pitumpulu \\
\hline 15 & Se(ce)mpulu lima & 80 & Alompulu \\
\hline 16 & Se(ce)mpulu enem & 90 & Siok(Ciok)mpulu \\
\hline 17 & Se(ce)mpulu pitu & 100 & Se(ce) ratus \\
\hline 18 & Se(ce)mpulu alo & 200 & Sua ratus \\
\hline 19 & Se(ce)mpulu siok(ciok) & 1000 & Ce ribu (ce sebu) \\
\hline 20 & Suampulu & 10000 & Se(ce)mpulu ribu/Se(ce)mpulu sebu \\
\hline$\ldots$ & $\ldots$ & $\ldots$ & ... \\
\hline
\end{tabular}

Dari Tabel 1 di atas dapat diketahui bahwa untuk bilangan 1 - 10 masing-masing mempunyai nama atau sebutan yang berbeda. Selanjutnya, untuk bilangan 10 - 90 terdapat tambahan fonem $/ \mathrm{m} /$ dan diikuti kata pulu dari bilangan $1-9$, dan khusus untuk bilangan 10 , $10^{2}, 100^{3}$, dan seterusnya ada perubahan bunyi dari /a/ menjadi /e/, seperti se(ce)mpulu, suampulu, telumpulu, dan seterusnya. Sedangkan bilangan 11 - 19 merupakan gabungan dari bilangan 10 - 90 dengan bilangan $1-9$, seperti se(ce)mpulu ca, se(ce)mpulu sua, se(ce)mpulu telu, ..., se(ce)mpulu siok(ciok), suampulu sa/ca, suampulu sua, suampulu telu, ..., suampulu siok/ciok, telumpulu sa(ca), telumpulu sua, telumpulu telu, dan seterusnya sampai dengan siok(ciok)mpulusiok(ciok).

Lebih lanjut, untuk bilangan 100 - 900 disebut se(ce) ratus, sua ratus, telu ratus, dan seterusnya sampai dengan siok(ciok) ratus. Hal yang sama berlaku untuk bilangan 1000, 2000, 3000, dan seterusnya disebut dengan ce ribu (ce sebu), sua ribu (sua sebu), telu ribu (telu sebu), 
dan seterusnya. Konstruksi bilangan yang lebih dari 10 dapat dilihat pada tabel berikut.

Tabel 2. Konstruksi Bilangan dalam Budaya Manggarai

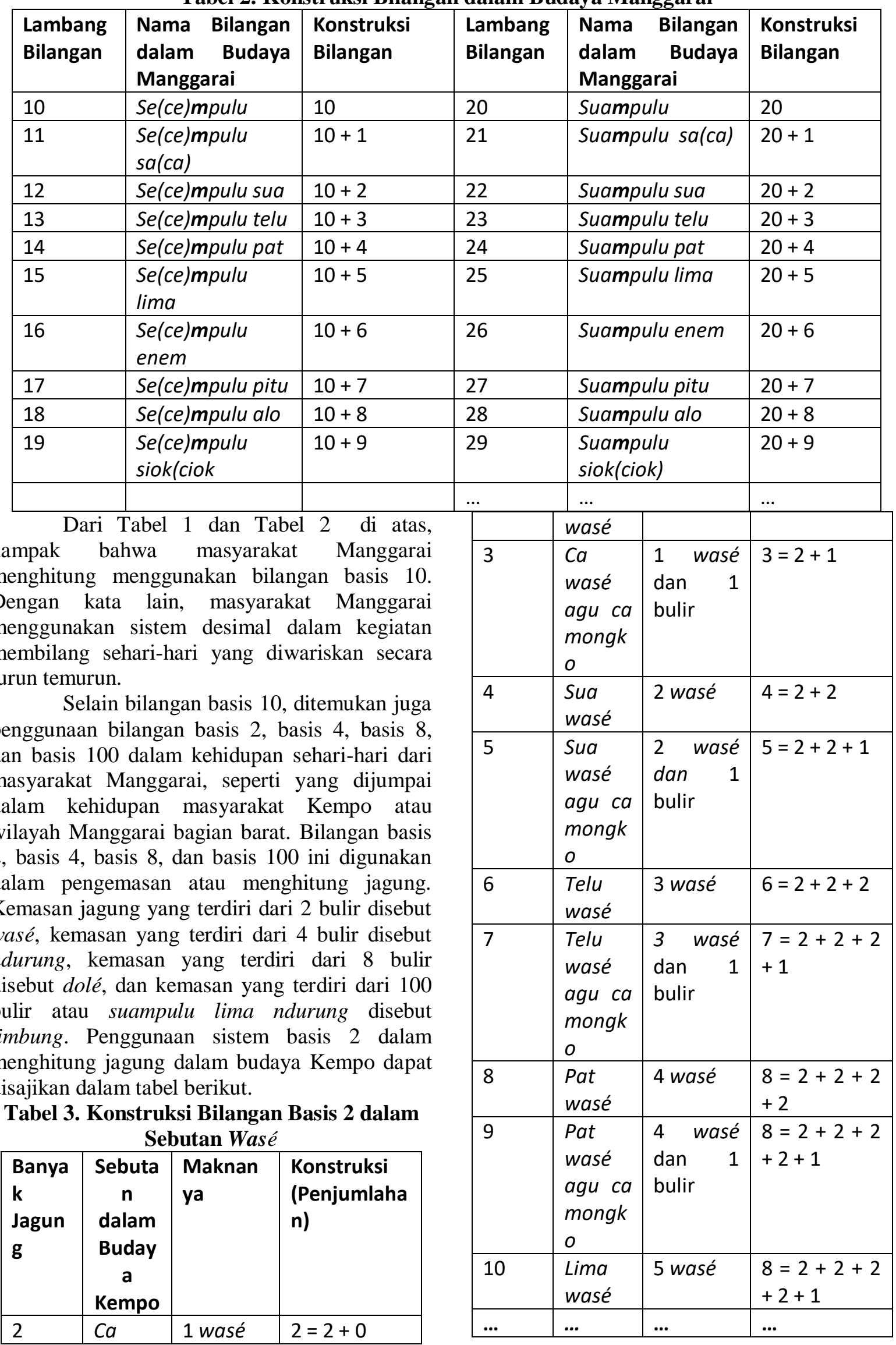


Sedangkan jika menghitung jagung Manggarai (Kempo) dapat dilihat sebagaimana menggunakan basis 4 menurut budaya disajikan dalam tabel berikut.

Tabel 4. Konstruksi Bilangan Basis 4 dalam Sebutan Ndurung

\begin{tabular}{|c|c|c|c|c|c|c|c|}
\hline $\begin{array}{l}\text { Banyak } \\
\text { Jagung }\end{array}$ & \multicolumn{3}{|c|}{ Sebutan dalam Budaya Kempo } & \multicolumn{2}{|c|}{ Maknanya } & \multicolumn{2}{|c|}{$\begin{array}{l}\text { Konstruksi } \\
\text { (Penjumlahan) }\end{array}$} \\
\hline 4 & \multicolumn{3}{|c|}{ Ca ndurung } & \multicolumn{2}{|l|}{1 ndurung } & \multicolumn{2}{|l|}{$4=4+0$} \\
\hline 5 & \multicolumn{3}{|c|}{ Ca ndurung agu ca mongko } & \multicolumn{2}{|c|}{1 ndurung dan 1 bulir } & \multicolumn{2}{|l|}{$5=4+1$} \\
\hline 6 & \multicolumn{3}{|c|}{ Ca ndurung agu ca wasé } & \multicolumn{2}{|c|}{1 ndurung dan 1 wasé } & \multicolumn{2}{|l|}{$6=4+2$} \\
\hline 7 & \multicolumn{3}{|c|}{$\begin{array}{l}\text { Ca ndurung, ca wasé, agu ca } \\
\text { mongko }\end{array}$} & \multicolumn{2}{|c|}{$\begin{array}{l}1 \text { ndurung, } 1 \text { wasé, dan } \\
1 \text { bulir }\end{array}$} & \multicolumn{2}{|c|}{$6=4+2+1$} \\
\hline 8 & \multicolumn{3}{|c|}{ Sua ndurung } & \multicolumn{2}{|l|}{2 ndurung } & \multicolumn{2}{|l|}{$8=4+4$} \\
\hline 9 & \multicolumn{3}{|c|}{ Sua ndurung agu ca mongko } & \multicolumn{2}{|c|}{2 ndurung dan 1 bulir } & \multicolumn{2}{|c|}{$9=4+4+1$} \\
\hline 10 & \multicolumn{3}{|c|}{ Sua ndurung agu ca wasé } & \multicolumn{2}{|c|}{2 ndurung dan 1 wasé } & \multicolumn{2}{|c|}{$10=4+4+2$} \\
\hline 11 & \multicolumn{3}{|c|}{$\begin{array}{l}\text { Sua ndurung, ca wasé, agu ca } \\
\text { mongko }\end{array}$} & \multicolumn{2}{|c|}{$\begin{array}{l}2 \text { ndurung, } 1 \text { wasé, dan } \\
1 \text { bulir }\end{array}$} & \multicolumn{2}{|c|}{$11=4+4+2+1$} \\
\hline 12 & \multicolumn{3}{|c|}{ Telu ndurung } & \multicolumn{2}{|l|}{3 ndurung } & \multicolumn{2}{|c|}{$12=4+4+4$} \\
\hline 13 & \multicolumn{3}{|c|}{ Telu ndurung agu ca mongko } & \multicolumn{2}{|c|}{3 ndurung dan 1 bulir } & $13=4+4$ & $+4+1$ \\
\hline 14 & Telu nds & rung agu & wasé & 3 ndurung & n 1 wasé & $14=4+4$ & $+4+2$ \\
\hline 15 & $\begin{array}{l}\text { Telu no } \\
\text { mongko }\end{array}$ & Arung, ca & vasé agu ca & $\begin{array}{l}3 \text { ndurung } \\
1 \text { bulir }\end{array}$ & wasé, dan & $14=4+4$ & $+4+2+1$ \\
\hline 16 & Pat ndu & ung & & 4 ndurung & & $16=4+4$ & $+4+4$ \\
\hline 17 & Pat ndu & ung agu $c$ & nongko & 4 ndurung & n 1 bulir & $17=4+4$ & $+4+4+1$ \\
\hline 18 & Pat ndu & ung agu $\mathrm{c}$ & Nasé & 4 ndurung & n 1 wasé & $18=4+4$ & $+4+4+2$ \\
\hline 19 & $\begin{array}{l}\text { Pat nd } \\
\text { mongko }\end{array}$ & rung, ca & 'asé, agu ca & $\begin{array}{l}4 \text { ndurung } \\
1 \text { bulir }\end{array}$ & wasé, dan & $\begin{array}{l}19=4+4 \\
+1\end{array}$ & $+4+4+2$ \\
\hline 20 & Limand & Irung & & 5 ndurung & & $20=4+4$ & $+4+4+4$ \\
\hline$\ldots$ & $\ldots$ & & & $\ldots$ & & $\ldots$ & \\
\hline $\begin{array}{r}\text { Da } \\
\text { as bahwa } \\
\text { sis } \quad 10\end{array}$ & $\begin{array}{l}\text { Tabel } 3 \\
\text { selain } \mathrm{m} \\
\text { dalam }\end{array}$ & $\begin{array}{l}\text { lan Tabel } \\
\text { nguasai d } \\
\text { kehidup }\end{array}$ & $\begin{array}{l}\text { di atas, sangat } \\
\text { menggunakan } \\
\text { sehari-hari, }\end{array}$ & 9 & $\begin{array}{l}\text { Ca dolé } \\
\text { agu ca } \\
\text { mongk } \\
o\end{array}$ & $\begin{array}{|lr|}1 & \text { dolé } \\
\text { dan } & 1 \\
\text { bulir } & \\
\end{array}$ & $9=8+1$ \\
\hline $\begin{array}{l}\text { asyarakat } \\
\text { ngan bil } \\
\text { sis } 8 \text { dan }\end{array}$ & $\begin{array}{l}\text { Manggar } \\
\text { ngan bas } \\
\text { pasis } 100 .\end{array}$ & $\begin{array}{l}\text { i } \text { (Kemp } \\
\text { s } 2 \text { dan } \\
\text { Pengguna }\end{array}$ & $\begin{array}{l}\text { sangat akrab } \\
\text { sis } 4 \text {, bahkan } \\
\text { bilangan basis }\end{array}$ & 10 & $\begin{array}{l}\text { Ca dolé } \\
\text { agu ca } \\
\text { wasé }\end{array}$ & $\begin{array}{|lr|} & \text { dolé } \\
\text { dan r r } & 1 \\
\text { wasé } & \\
\end{array}$ & $10=8+2$ \\
\hline $\begin{array}{l}\text { Kempo) } \\
\text { nengemas } \\
\text { usunan da } \\
\text { nasing-mas } \\
\text { imbung. I } \\
\text { ebagaiman }\end{array}$ & $\begin{array}{l}\text { Is lopat di } \\
\text { dan me } \\
\text { jumlah } \\
\text { ing diken } \\
\text { ntuk leb } \\
\text { disajika }\end{array}$ & $\begin{array}{l}\text { alam but dari } \\
\text { ghitung } \\
\text { bulir dan } \\
\text { l dengan } \\
\text { jelasny } \\
\text { dalam d }\end{array}$ & $\begin{array}{l}\text { a Manggaral } \\
\text { cara mereka } \\
\text { gung dengan } \\
\text { 00 bulir, yang } \\
\text { sutan dolé dan } \\
\text { dapat dilihat } \\
\text { tabel berikut }\end{array}$ & 11 & $\begin{array}{l}\text { Ca dolé, } \\
\text { ca } \\
\text { wasé, } \\
\text { agu ca } \\
\text { mongk } \\
\text { o }\end{array}$ & $\begin{array}{|ll|}1 \text { dolé, } & 1 \\
\text { wasé, } & \\
\text { dan } & 1 \\
\text { bulir } & \end{array}$ & $11=8+2+1$ \\
\hline Tabel 5.1 & $\begin{array}{r}\text { onstruks } \\
\text { Seb }\end{array}$ & $\begin{array}{l}\text { Bilangan } \\
\text { tan Dolé }\end{array}$ & is 8 dalam & 12 & $\begin{array}{l}\text { Ca dolé } \\
\text { agu ca } \\
\text { ndurun }\end{array}$ & $\begin{array}{|lr|}1 & \text { dolé } \\
\text { dan } & 1 \\
\text { ndurung }\end{array}$ & $12=8+4$ \\
\hline Banya & Sebuta & & Konstruksi & & & & \\
\hline \begin{tabular}{|l}
$\mathbf{k}$ \\
Jagun \\
$\mathbf{g}$
\end{tabular} & $\begin{array}{l}\mathrm{n} \\
\text { dalam } \\
\text { Budaya } \\
\text { Kempo } \\
\end{array}$ & ya & $\begin{array}{l}\text { (Penjumlaha } \\
\text { n) }\end{array}$ & 13 & $\begin{array}{l}\text { Ca dolé, } \\
c a \\
\text { ndurun } \\
g \quad a g u\end{array}$ & 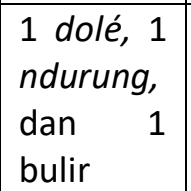 & $\begin{array}{l}13=8+4+ \\
1\end{array}$ \\
\hline 8 & Ca dolé & 1 dolé & $8=8+0$ & & & & \\
\hline
\end{tabular}




\begin{tabular}{|c|c|c|c|}
\hline & $\begin{array}{l}\text { mongk } \\
o\end{array}$ & & \\
\hline 14 & $\begin{array}{l}\text { Ca dolé, } \\
c a \\
\text { ndurun } \\
g \text { agu } \\
\text { ca } \\
\text { wasé }\end{array}$ & $\begin{array}{l}1 \text { dolé, } 1 \\
\text { ndurung, } \\
\text { dan } 1 \\
\text { wasé }\end{array}$ & $14=8+4+2$ \\
\hline 15 & $\begin{array}{l}\text { Ca dolé, } \\
\text { ca } \\
\text { ndurun } \\
g, \quad c a \\
\text { wasé, } \\
\text { agu ca } \\
\text { mongk } \\
\text { o }\end{array}$ & $\begin{array}{l}1 \text { dolé, } 1 \\
\text { ndurung, } \\
1 \text { wasé, } \\
\text { dan } 1 \\
\text { bulir }\end{array}$ & $\begin{array}{l}15=8+4+2 \\
+1\end{array}$ \\
\hline 16 & $\begin{array}{l}\text { Sua } \\
\text { dolé }\end{array}$ & $\begin{array}{lr}2 & \text { dolé } \\
\text { atau } & 16 \\
\text { bulir } & \\
\end{array}$ & $16=8+8$ \\
\hline 17 & $\begin{array}{l}\text { Sua } \\
\text { dolé } \\
\text { agu ca } \\
\text { mongk } \\
\text { o } \\
\end{array}$ & $\begin{array}{lr}2 & \text { dolé } \\
\text { dan } & 1 \\
\text { bulir } & \end{array}$ & $\begin{array}{l}17=8+8+ \\
1\end{array}$ \\
\hline 18 & $\begin{array}{l}\text { Sua } \\
\text { dolé } \\
\text { agu ca } \\
\text { wasé }\end{array}$ & $\begin{array}{lr}2 & \text { dolé } \\
\text { dan } 1 \\
\text { wasé }\end{array}$ & $18=8+8+2$ \\
\hline 19 & $\begin{array}{l}\text { Sua } \\
\text { dolé, ca } \\
\text { wasé, } \\
\text { agu ca } \\
\text { mongk } \\
\text { o }\end{array}$ & $\begin{array}{ll}2 \text { dolé, } & 1 \\
\text { wasé, } & \\
\text { dan } & 1 \\
\text { bulir } & \end{array}$ & $\begin{array}{l}19=8+8+2 \\
+1\end{array}$ \\
\hline 20 & $\begin{array}{l}\text { Sua } \\
\text { dolé } \\
\text { agu ca } \\
\text { wasé }\end{array}$ & $\begin{array}{lr}2 & \text { dolé } \\
\text { dan } & 1 \\
\text { wasé } & \end{array}$ & $20=8+8+2$ \\
\hline$\ldots$ & $\ldots$ & $\ldots$ & $\ldots$ \\
\hline
\end{tabular}

Tabel 6. Konstruksi Bilangan Basis 100 dalam Sebutan Limbung

\begin{tabular}{|l|l|l|l|}
\hline $\begin{array}{l}\text { Bany } \\
\text { ak } \\
\text { Jagun } \\
\mathbf{g}\end{array}$ & $\begin{array}{l}\text { Sebuta } \\
\mathbf{n} \\
\text { dalam } \\
\text { Buday } \\
\text { a } \\
\text { Kempo }\end{array}$ & $\begin{array}{l}\text { Maknan } \\
\text { ya }\end{array}$ & $\begin{array}{l}\text { Konstruksi } \\
\text { (Penjumlahan) }\end{array}$ \\
\hline 100 & $\begin{array}{l}\text { Ca } \\
\text { limbun } \\
g\end{array}$ & $\begin{array}{l}1 \\
\text { limbung }\end{array}$ & $100=100+0$ \\
\hline
\end{tabular}

\begin{tabular}{|c|c|c|c|}
\hline 101 & $\begin{array}{l}\text { Ca } \\
\text { limbun } \\
g \text { agu } \\
\text { ca } \\
\text { mongk } \\
o\end{array}$ & $\begin{array}{l}1 \\
\text { limbung } \\
\text { dan } 1 \\
\text { bulir }\end{array}$ & $101=100+1$ \\
\hline 102 & $\begin{array}{l}\text { Ca } \\
\text { limbun } \\
g \text { agu } \\
\text { ca } \\
\text { wasé }\end{array}$ & $\begin{array}{l}1 \\
\text { limbung } \\
\text { dan } 1 \\
\text { wasé }\end{array}$ & $102=100+2$ \\
\hline 103 & $\begin{array}{l}\text { Ca } \\
\text { limbun } \\
\text { g, ca } \\
\text { wasé, } \\
\text { agu ca } \\
\text { mongk } \\
o\end{array}$ & $\begin{array}{l}1 \\
\text { limbung, } \\
1 \text { wasé, } \\
\text { dan } 1 \\
\text { bulir }\end{array}$ & $\begin{array}{l}103=100+2 \\
+1\end{array}$ \\
\hline 104 & $\begin{array}{l}\text { Ca } \\
\text { limbun } \\
g \text { agu } \\
\text { ca } \\
\text { ndurun } \\
g \\
\end{array}$ & $\begin{array}{l}1 \\
\text { limbung } \\
\text { dan } 1 \\
\text { ndurung }\end{array}$ & $104=100+4$ \\
\hline 105 & $\begin{array}{l}\text { Ca } \\
\text { limbun } \\
g, \quad c a \\
\text { ndurun } \\
g \quad a g u \\
c a \\
\text { mongk } \\
o\end{array}$ & $\begin{array}{l}1 \\
\text { limbung, } \\
1 \\
\text { ndurung } \\
\text { dan } 1 \\
\text { bulir }\end{array}$ & $\begin{array}{l}105=100+4 \\
+1\end{array}$ \\
\hline 106 & $\begin{array}{l}\text { Ca } \\
\text { limbun } \\
g, \quad \text { ca } \\
\text { ndurun } \\
g \quad \text { agu } \\
\text { ca } \\
\text { wasé }\end{array}$ & $\begin{array}{l}1 \\
\text { limbung, } \\
1 \\
\text { ndurung } \\
\text {, dan } 1 \\
\text { wasé }\end{array}$ & $\begin{array}{l}106=100+4 \\
+2\end{array}$ \\
\hline 107 & $\begin{array}{l}\text { Ca } \\
\text { limbun } \\
g, \quad c a \\
\text { ndurun } \\
g, \quad c a \\
\text { wasé, } \\
\text { agu ca } \\
\text { mongk } \\
o\end{array}$ & $\begin{array}{l}1 \\
\text { limbung, } \\
1 \\
\text { ndurung } \\
\text {, } 1 \text { wasé, } \\
\text { dan } 1 \\
\text { bulir }\end{array}$ & $\begin{array}{l}107=100+4 \\
+2+1\end{array}$ \\
\hline 108 & $\begin{array}{l}\text { Ca } \\
\text { limbun } \\
g \quad \text { agu }\end{array}$ & $\begin{array}{l}1 \\
\text { limbung } \\
\text { dan } \quad 2\end{array}$ & $\begin{array}{l}108=100+4 \\
+4\end{array}$ \\
\hline
\end{tabular}




\begin{tabular}{|c|c|c|c|}
\hline & $\begin{array}{l}\text { sua } \\
\text { ndurun } \\
g\end{array}$ & ndurung & \\
\hline 109 & $\begin{array}{l}\text { Ca } \\
\text { limbun } \\
g, \text { sua } \\
\text { ndurun } \\
g \text { agu } \\
\mathrm{ca} \\
\text { mongk } \\
o\end{array}$ & $\begin{array}{l}1 \\
\text { limbung, } \\
2 \\
\text { ndurung } \\
\text {, dan } 1 \\
\text { bulir }\end{array}$ & $\begin{array}{l}109=100+4 \\
+4+1\end{array}$ \\
\hline 110 & $\begin{array}{l}\text { Ca } \\
\text { limbun } \\
g \text {, sua } \\
\text { ndurun } \\
g \text { agu } \\
\text { ca } \\
\text { wasé }\end{array}$ & $\begin{array}{l}1 \\
\text { limbung, } \\
2 \\
\text { ndurung } \\
\text {, dan } 1 \\
\text { wasé }\end{array}$ & $\begin{array}{l}110=100+4 \\
+4+2\end{array}$ \\
\hline$\ldots$ & $\ldots$ & $\ldots$ & $\ldots$ \\
\hline 200 & $\begin{array}{l}\text { Sua } \\
\text { limbun } \\
g\end{array}$ & $\begin{array}{l}2 \\
\text { limbung }\end{array}$ & $\begin{array}{l}200=100+ \\
100\end{array}$ \\
\hline 300 & $\begin{array}{l}\text { Telu } \\
\text { limbun } \\
g\end{array}$ & $\begin{array}{l}3 \\
\text { limbung }\end{array}$ & $\begin{array}{l}300=100+ \\
100+100\end{array}$ \\
\hline 400 & $\begin{array}{l}\text { Pat } \\
\text { limbun } \\
g\end{array}$ & $\begin{array}{l}4 \\
\text { limbung }\end{array}$ & $\begin{array}{l}400= \\
100+100+100+ \\
100\end{array}$ \\
\hline$\ldots$ & $\ldots$ & $\ldots$ & $\ldots$ \\
\hline
\end{tabular}

Dari Tabel 5 dan Tabel 6 di atas, dapat dikatakan bahwa masyarakat Manggarai (Kempo) dapat juga melakukan perhitungan menggunakan basis 8 dan basis 100. Dari cara mereka melakukan kegiatan menghitung dan mengemas jagung yang diwariskan secara turuntemurun ternyata masyarakat Manggarai (Kempo) sudah mengenal bilangan basis nondesimal, yaitu bilangan basis 2 (duo-desimal), basis 4, basis 8, dan basis 100 .

\section{LITERASI BILANGAN DALAM RITUAL ADAT MANGGARAI}

Pembelajaran literasi bilangan dapat dilakukan atau ditemukan oleh peserta didik dalam pelaksanaan ritual adat tertentu di lingkungan tempat tinggal mereka. Sebutan atau nama bilangan dalam konteks masyarakat Manggarai sebagaimana yang sudah diuraikan sebelumnya, ada yang bermakna kultural jika dalam penggunaannya digabungkan dengan istilah lain. Konsep-konsep membilang yang digunakan dalam konteks budaya atau ritual adat adalah konsep ca, lima, dan ce(pulu), seperti terlihat padat ritual berikut.

Ceki lima, digunakan dalam konteks orang mati (upacara adat mengenang dan mendoakan keselamatan arwah dari orang yang sudah meninggal pada hari ke-lima, yang dihitung sejak setelah dikuburkan). Penggunaan konsep lima (lima) selalu dihubungkan dengan konsep cepulu (sepuluh), seperti pada ungkapan: Curu le hau lampék pulu, agu timbang le hau lampék lima; Diungkapkan pada saat wada ela haéng nai (ca ela, satu ekor babi), yang artinya: terimalah peristiwa kematian ini jika memang karena ajalmu (lampék pulu), tetapi engkau pula yang harus mencari orang yang menyebabkan kematianmu jika kematianmu karena kuasa duniawi atau karena krénda data cama haé manusia (lampék lima).

Ceki lima juga digunakan dalam konteks kelahiran. Pada saat jelang melahirkan (jika melahirkan dalam keadaan yang sulit/terancam keselamata jiwa sang ibu dan/atau bayi). Penggunaan konsep lima (lima) selalu dihubungkan dengan konsep cepulu (sepuluh), seperti pada ungkapan: Omé curu lampék pulu tai, tama kéta loas; agu omé timbang le hau lampék lima, tama kéta néka le pai lunin kali, yang artimya memohon kepada Tuhan sambil berpasrah supaya bisa melahirkan dengan selamat, dan jika memang terjadi hal yang tidak diinginkan maka lagi-lagi berharap pada kemurahan dan kasih Tuhan agar selamatkan jiwa ibunya.

Ungkapan tersebut, biasanya dilanjutkan dengan ungkapan berikut: Émé kudut léwé lé lonto oné lino, ko kudut manga oné lino, ca manuk bakok kéta le hami, kapu ného wua pau agu naka ného wua nangka. Ungkapan di atas diucapkan pada saat wada sambil memegang $\boldsymbol{c a}$ manuk lalong bakok (seekor ayam putih jantan), yang menunjukkan sikap memohon penuh kepasrahan sambil bersumpah janji dalam nada syukur) menjelangkan "melahirkan dalam kondisi terancam keselamatan jiwa sang ibu atau bayi".

Ceki lima juga berhubungan dengan acara céhar cumpé, yaitu suatu upacara adat sebagai ungkapan syukur dan terima kasih kepada Tuhan YME (mori kraéng) atas peristiwa "kelahiran", yang dilanjutkan dengan acara loda putes (pemotongan tali pusat dari bayi). Upacara ini dilakukan pada hari ke-lima terhiung sejak bayi lahir, yang ditandai dengan pemotongan $\boldsymbol{c a}$ manuk lalong bakok sebagai persembahan tanda 
syukur kepada Tuhan (mori kraéng) dan leluhur. Selama berada dekat perapian atau oné lupi sapo yaitu selama lima hari terhitung sejak bayi lahir, sang ibu menggunakan ca boték tau penes weki agu bara (menggunakan sepotong kain bekas untuk mengambil panas api dan digunakan selanjutnya untuk menghangatkan badan si bayi, lebih-lebih pada bagian perutnya) sampai acara céhar cumpé dilaksanakan.

Jika ritual adat seperti diuraikan di atas tidak dilakukan maka cepat atau lambat akan mendapat kutukan (manga nangki) dari mori kraéng dan leluhur. Cepat lambatnya nangki (kutukan) sangat tergantung pada tingkat kemarahan dari mori kraéng dan leluhur.

Konsep membilang yang lain, yang sering digunakan (selain ca, lima, dan cepulu) adalah sua, telu, pat, suampulu, telumpulu, dan limampulu. Konsep-konsep tersebut sering muncul dalam penentuan bélis (sejumlah harta berupa hewan kerbau atau kuda, emas, dan uang) atau waktu nempung dalam acara perkawninan adat. Konsep-konsep itu dapat diungkapkan dalam penentuan bélis atau nempung.

Waktu penentuan bélis, misalnya disepakati sua atau telu atau lima atau cepulu kaba (kerbau); lima atau cepulu jarang (kuda); dan suampulu rupia atau telumpulu rupia atau limampulu rupia séng. Waktu nempung, misalnya disepakati tau cikat kina, suan kina mbelé; atau tau wagal, telun kaba mbelé.

\section{LITERASI MEMBILANG DAN PENGGUNAANNYA DALAM BUDAYA MANGGARAI}

Berbagai jenis alat bantu yang sering digunakan oleh masyarakat Manggarai untuk membilang antara lain: jari tangan, jagung, dukut ré'a. Pemakain alat hitung tersebut umumnya relatif sama.

Pemaikain jari tangan digunakan untuk membilang obyek yang jumlahnya relatif kecil dan mendesak. Sedangkan penggunaan jagung dan dukut ré'a untuk membilang obyek yang jumlahnya relatif banyak. Pada masa-masa masyarakat Manggarai belum mengenal kelender, jagung dan dukut ré'a ini yang dijadikan sebagai patokan.

Sebagai misal, ada pertemuan tentang acara adat tertentu misalnya wagal. Acara ini misalnya dilaksanakan 30 hari lagi. Tehnik yang biasa digunakan saat itu adalah mereka mengambil wasé ré'a (tali ré'a) dibuat dukut (simpul) sebanyak 30 dan antara dukut yang satu dan yang lainnya ada jarak sekitar $1 \mathrm{~cm}$. Selanjutnya dukut ré'a tersebut digantung pada tempat tertentu yang relatif aman. Setiap pagi orang yang sudah diberi tugas oleh tu'a menggunting satu dukut. Hal ini berarti setiap hari berkurang satu dukut. Kalau sisa dukut tersebut hanya ada satu hal itu memberikan informasi kepada mereka bahwa hari puncak (leso reké) kegiatan tersebut dilaksanakan tepat satu hari lagi atau besoknya. Pada saat hari puncak kegiatan dukut yang tadi sisa satu buah saja digunting (keti) dan dibuang sehingga muncul istilah keti riket.

Cara yang lain menggunakan jagung sebanyak 30 buah. Jagung tersebut disimpan dalam satu wadah yang dinamakan teru. Setiap pagi, ada orang yang ditugaskan secara khusus oleh tu'a untuk mengambil satu dari jagung tersebut untuk dibuang. Dengan demikian jagung tersebut akan berkurang sebanyak 1 buah setiap harinya. Sedangkan jika kegiatan membilang dilakukan di luar rumah, maka alat peraga yang sering digunakan adalah wua kopi (buah kopi, umumnya buah kopi yang sudah masak atau yang berwarna merah).

\section{LITERASI MENGUKUR DALAM BUDAYA MANGGARAI}

Pengukuran merupakan penentuan besaran, dimensi, atau kapasitas, biasanya terhadap suatu standar atau satuan pengukuran. Mengukur merupakan aktivitas yang biasa dilakukan dalam proses jual beli atau barter, rancang bangun, menentukan tinggi, panjang, keliling, luas, kedalaman, kecepatan dan sebagainya. Pengukuran yang dilakukan oleh masyarakat Manggarai pada jaman dulu menggunakan alat-alat ukur yang tidak baku misalnya penggunaan angota badan seperti jari tangan, depa, jengkal atau menggunakan alat ukur berupa benda yang berukuran satu depa untuk mengukur panjang, dan tongka untuk mengukur volume.

Satuan pengukuran yaitu ukuran dari suatu besaran yang digunakan dalam pengukuran menyesuaikan dengan alat ukurnya, misalnya satuan dalo, héndok, pagat, ciku, depa, dako, tongka, wega dan sebagainya. Besaran waktu mempunyai satuan leso(hari), minggu(minggu), lu'ang/wulang (bulan), ntaung(tahun), dan sebagainya.

Alat ukur untuk mengukur panjang yang biasa digunakan adalah wasé Ntawang/Ndawang dan wasé ajo (dua jenis tali yang tergolong 
panjang, kuat, dan tahan lama). Alat ukur wasè Ntawang/Ndawang dan wasé ajo ini digunakan untuk mengukur panjang pada umumnya, yang satuannya adalah meter.

Satuan ukur panjang yang biasa digunakan oleh masyarakat Manggarai adalah; dalo (ruas jari), héndok (sepanjang telapak tangan), pagat (jengkal), ciku (siku), depa (depa) dan lampa (langkah). Penggunaan masingmasing alat ukur tersebut dapat dijelaskan sebagai berikut:

\section{Dalo}

$\mathrm{Ca}$ Dalo digunakan untuk menyatakan panjang tanduk kerbau, yang panjangnya diukur dari ujung jari (tengah) sampai dengan ruas pertama. $\mathrm{Ca}$ dalo hang, digunakan untuk menyatakan panjang tanduk kerbau, yang panjangnya diukur dari ujung jari (tengah) sampai dengan tengah-tengah telapak tangan.

\section{Héndok}

Ca héndok, digunakan untuk menyatakan panjang tanduk kerbau, yang panjangnya diukur dari ujung jari tengah sampai dengan pergelangan tangan.

\section{Pagat}

Pagat digunakan untuk mengukur tanduk kerbau. Jika ukuran tersebut lebih dari satu pagat maka gunakan jari. Ukuran satu pagat ditambah satu jari dikatakan tabal sa. Ukuran satu pagat ditambah dua jari disebut tabal sua. Ukuran satu pagat ditambah tiga jari disebut tabal telu. Ukuran satu pagat ditambah empat jari disebut tabal pat. Ukuran satu pagat ditambah lima jari disebut tabal lima. Selanjutnya jika ukuran satu pagat tambah lima jari lebih maka itu disebut tabal tongkéng ponggo.

4. Ciku

$\mathrm{Ca}$ ciku, digunakan untuk menyatakan ukuran lingkar leher babi yang paling besar. Selain itu $\mathrm{Ca}$ ciku juga dapat berarti ukuran panjang yang sama dengan ca pagat + ca héndok.

\section{Depa}

Ca depa, digunakan untuk menyatakan ukuran panjang suatu benda misalnya kayu balok, bantal, ukuran lahan dan lain-lain. Tehnik yang biasa digunakan misalnya untuk mengukur balok adalah, pilih kayu yang berukuran kecil. Kayu tersebut diukur dari ujung jari tengah tangan kiri hingga ujung jari tengah tangan kanan. Ca depa sering disepakati sebagai satu meter.

\section{Lampa}

Lampa digunakan untuk mengukur jarak di tanah rata.

\section{Ukuran khusus Tentang Besarnya} Badan Kerbau

Sebutan untuk ukuran besarnya badan kerbau, selain diukur berdasarkan ukuran panjang tanduknya juga dapat diukur dengan sebutan khusus berikut.

a. Sua ngi'is, setara dengan ukuran tanduk yang panjangnya ca héndok

b. Pat ngi'is, setara dengan ukuran tanduk yang panjangnya ca héndok lebih tetapi kurang dari ca ciku

c. Enem ngi'is, setara dengan ukuran tanduk yang panjangnya ca ciku

d. Alo ngi'is, setara denganukuran tanduk yang panjangnya $c a c i k u$ lebih

Selanjutnya, alat ukur untuk mengukur luas (terutama luas kebun) yang diguakan dalam kehidupan masyarakat Manggarai adalah moso. Ukuran luas yang sering digunakan terutama dalam pembagian tanah kebun/ladang adalah: $c a$ moso, sua moso, telu moso, pat moso, dan lima moso. Moso (jari) yang digunakan sangat tergantung pada strata sosial atau fungsi/kedudukan seseorang dalam masyarakat adat, yaitu:

1. Untuk tu'a golo menggunakan ponggo (ibu jari)

2. Untuk tu'a teno menggunakan moso toso (jari telunjuk)

3. Untuk tu'a panga menggunakan moso landong (jari tengah)

4. Untuk pa'ang olo ngaung musi menggunakan moso kila (jari manis),

5. Untuk ata kapu manuk agu lélé tuak menggunakan moso kindé.

Penggunaan alat ukur moso tersebut menjamin keadilan pada jaman tersebut. Tu'a golo hak perolehan lahannya menggunakan ponggo tentu ukuran luas lahannya agak besar dibandingkan dengan yang lainnya.hal ini karena tu'a golo memiliki tanggung jawab besar dalam kehidupan di kampung tersebut.

Masyarakat Manggarai mengenal juga alat yang digunakan untuk mengukur volume. Alat-alat tersebut antara lain: tongka, roto ci'é, warang, wega/gantang, béka, langkok/labak, dan cécér/lancing. 
Ukuran volum yang sering digunakan dalam kehidupan masyarakat Manggarai adalah: dako, tongka, roto ci'é, warang, wega/gantang, béka, langkok/labak, dan cécér /lancing.
1. Ca dako $=1$ genggam
2. Ca tongka $=5 \mathrm{~kg}$
3. Ca roto ci'é $=$ sua tongka $=10 \mathrm{~kg}$
4. Ca warang $=$ pat tong $\mathrm{ka}=20 \mathrm{~kg}$
5. Ca wega/gantang = sua warang = alo tong $\mathrm{ka}=40 \mathrm{~kg}$
6. Ca béka $=$ sua wega $=80 \mathrm{~kg}$
7. Ca langkok/ca labak $\leq 10$ béka
8. Ca cécér/lancing $\leq 10$ béka

\section{KESIMPULAN}

Uraian dalam tulisan ini merupakan pengetahuan matematika terutama mengenai konsep membilang dan mengukur yang dikaitkan dengan konteks budaya masyarakat Manggarai. Konsep-konsep membilang yang digunakan dalam konteks budaya atau ritual adat masyarakat Manggarai adalah konsep ca, lima, dan ce(pulu), seperti terlihat pada ritual adat tertentu.

Demikian halnya aktivitas mengukur yang dilakukan oleh masyarakat Manggarai, menggunakan alat-alat ukur yang tidak baku misalnya penggunaan anggota badan seperti jari tangan, jengkal, depa atau menggunakan alat ukur berupa benda yang berukuran satu depa untuk mengukur panjang, dan tongka untuk mengukur volume. Satuan pengukuran yaitu ukuran dari suatu besaran yang digunakan dalam pengukuran menyesuaikan dengan alat ukurnya, misalnya satuan dalo, héndok, pagat, ciku, depa, dako, tongka, wega dan sebagainya. Besaran waktu mempunyai satuan leso, minggu, lu'ang/wulang, ntaung, dan sebagainya.

\section{DAFTAR RUJUKAN}

Dapur, Lambertus. 2015. Informan Kunci (Tu'a Golo Kampung Ruteng Pu.u), yang diwawancarai pada Sabtu, 11 April 2015.

Hartono, Y., dkk. 2008. Pengembangan pembelajaran matematika SD, Direktorat Jendral Pendidikan Tinggi Nasional.

Hartono, A. 2012. Eksplorasi etnomatematika pada budaya masyarakat Dayak perbatasan Indonesia-Malaysia Kabupaten Sanggau Kalbar. Jurnal Penelitian Pendidikan Vol. 13 No. 1, April 2012: 14-23, ISSN 1412-565X
Matang, R.A. 2006. Linking ethnomathematics, situated cognition, social constructivism and mathematics education: An example from Рapua New Guinea, ICEM-3 Conference Paper, New Zealand

Palinusa, A. 2013. Meningkatkan kemampuan berpikir kritis dan kreatif matematis, pembinaan karakter dan budaya siswa melalui pembelajaran matematika realistik, Disertasi pada SPs UPI Bandung: Tidak Diterbitkan.

Pannen. 2005. Pembelajaran berbasis budaya: model inovasi pembelajaran dan implementasi kurikulum berbasis kompetensi. Jurnal Pendidikan, Vol.6, No.2, September 2005, 83-98

Sirete F.S. 2012. Implementasi etnomatematika dalam pembelajaran matematika pada jenjang pendidikan sekolah dasar. Jurnal Lentera Pendidikan, vol. 15 no. 1 Juni 2012: 41-54

Sugiyono. 2010. Metode penelitian kuantitatif kualitatif dan $R \& D$, Bandung: Penerbit Alfabeta.

, 2012. Metode penelitian kombinasi (Mixed Methods), Bandung:Penerbit Alfabeta.

Tamur, M., Sennen, E., Pantaleon, K. 2017. Etnomatematika daerah Manggarai Flores-NTT dalam tradisi belis dan pengukuran. Prosiding Seminar Nasional Matematika dan Pendidikan Matematika STKIP Siliwangi, Vol. 5 Tahun 2017. ISSN: 2338-8315

Tim Redaksi KBI. 2008. Kamus besar bahasa Indonesia, Jakarta: Pusat bahasa, Departemen Pendidikan Nasional

Wahyuni, A, dkk. 2013. Peran etnomatematika dalam membangun karakter bangsa, Prosiding, ISBN :978-979-16353-9-4

Zhang, W \& Z. Q. 2010. Ethnomathematics and its integration within the mathematics curriculum. Journal of Mathematics Education: June 2010, Vol. 3, No. 1, pp.151-157 